\title{
Investigating the Moderating Role of Social Support in Online Shopping Intentions
}

\author{
Samuel Antwi \\ School of Management and E-Business, Zhejiang Gongshang University, Hangzhou, 310018, China \\ samantwi88@outlook.com \\ $\mathrm{Wu} B \mathrm{Be}^{*}$ \\ School of Management and E-Business, Zhejiang Gongshang University, Hangzhou, China \\ wubei@mail.zjgsu.edu.cn \\ Moses Agyemang Ameyaw \\ School of Business Administration, Zhejiang Gongshang University, Hangzhou, China \\ mosesameyaw1@gmail.com
}

\begin{abstract}
Relationship building plays a crucial role in business success because of the saturated nature of the market. Thus, there has been stronger competition because many businesses offer similar products for sale on an online shopping platform. This has given online consumers a wide range of alternatives when shopping online. This present study aimed to investigate the influence of relationship quality on purchase intention among Ghanaian consumers in an online shopping platform while moderated by social support. A convenience sampling method was employed to collect 304 responses from the respondents via web-survey. Partial least square structural equation modeling (PLSSEM) was used to assess the structural model. The findings reveal that customer trust and customer satisfaction did not significantly influence purchase intention. Furthermore, Customer commitment and social support had a significant and positive influence on purchase intention. Also, social support moderated the relationship between customer trust and purchase intention but had no moderation effect on the relationship between customer satisfaction and purchase intention and customer commitment and purchase intention. This article ends with theoretical and practical implications.
\end{abstract}

Keywords: Relationship Quality, Consumer Behavior, Purchase Intention, Social Support, Ghana

DOI: $10.7176 / \mathrm{JMCR} / 78-04$

Publication date: April $30^{\text {th }} 2021$

\section{Introduction}

In recent years, the proliferation of the internet has provided another medium for companies to sell their product online. Online businesses have experienced significant growth over the past few years because of its wider coverage as compared to offline businesses. Many e-retailers compete in the same online market by offering the same or similar products to consumers. Thus, online consumers are presented with varieties of the same or similar products they intend to purchase. This intense competition has compelled most businesses to establish a strong customer relationships (Gilaninia et al., 2011). Besides, online consumers may receive advice or product recommendations from their friends when they intend to buy products.

Relationship quality is about forming a long-term business relationship with online consumers. According to Hennig-Thurau (2000), it is one of customer loyalty's key determinants, and loyal customers continue to buy from the same retailer because of their bonding relationship. Acquiring new customers is one of the difficult challenges that many online businesses are faced with; however, it is effortless for an online business to maintain its existing customers. Murphy and Murphy (2002) supported this claim and asserted that it could cost five times as much to bring in new customers as to maintain existing customers. In line with the above understanding, this study intends to explore the influence of relationship quality in an online purchase intention among Ghanaian consumers while moderated by social support. Relationship quality is a multi-dimensional construct with several dimensions. However, this research's relationship quality is customer trust, satisfaction, and commitment (Yang et al., 2010).

\section{Literature Review and Hypotheses Development}

Relationship quality is rooted in relationship marketing. Relationship marketing explains the effort of a company to build a lasting business relationship with their customers (Allaway et al., 2006) because of the market's competitive solid nature. Relationship quality is meant to strengthen the relationship between an e-retailer and their customers. Thus, these days many businesses focus on building marketing strategies that focus on building and maintaining a healthy relationship with their buyers.

Trust is one of the central subjects in online shopping because of its uncertainties (Pavlou, 2003), anonymity, possible opportunism and lack of control (Grabner-Kräuter \& Kaluscha, 2003). Trust denotes that an e-retailer is 
truthful and benevolent (Gustafsson et al., 2005). It is a belief that a person has that others will not take advantage of him/her in an exchange process (Beldad et al., 2010). When a customer places an order and makes payment in an online shopping context, he expects the e-retailer to fulfill his part based on the agreed terms and conditions. Thus, trust is established if an individual (online consumer) considers that the other party (e-retailer) he trusts will act acceptably following the agreed terms (Kim et al., 2004). Trust in the online shopping is classified into intermediary trust and seller trust (Verhagen et al., 2006). According to the researchers, the intermediary trust explains the trustworthiness of the intermediary that supports the website. In contrast, seller trust is the perception of trust in the party offering a product for sale. In past literature, trust has been found to influence a behavioral intention (Shin et al., 2013; Sullivan \& Kim, 2018; Yin et al., 2019).

Satisfaction is regarded as a critical factor that affect customer decision to purchase from an e-retailer. Satisfaction is defined by (Kim et al., 2004) as an emotional reaction to an online transaction. To Parker and Mathews (2001), it is a feeling that arises because of a difference in what is acceptable and expected, satisfying desires and needs. A customer is deemed to be satisfied when a particular service meets their expectations. A customer's decision to build a relationship with an e-retailer may be based on several encounters, including satisfaction. A satisfied customer is likely to remain loyal to the firm. Research has found out that satisfaction

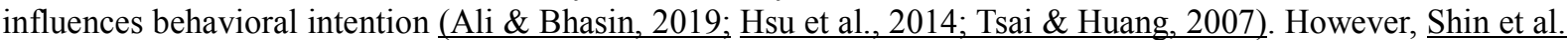
(2013) found out that satisfaction does not influence behavioral intention.

Relationship commitment is an individual desire to continue a business relationship, usually for a longer period (Wu et al., 2010). Commitment is viewed by Suh and Han (2003) as a strong feeling to maintain a bond with a brand. Commitment comprises three dimensions: normative commitment, affective commitment, and calculative commitment (Jones et al., 2010). Normative commitment is the moral way of doing things, and affective commitment focuses on how customers act towards an organization because of their feelings and emotions. In contrast, calculative commitment is based on how customers act because of their rational and economic reason. Prior studies have found that commitment influences behavioral intention (Amoako et al., 2019; Eisa Nauroozi et al., 2015; Hazra, 2013).

Social support denotes that members are cared for, loved and valued by other members in a social group. Thus, social support is a behavior that involves human interactions, usually in a social group or network, by which individual shares and receives an instrumental, emotional, or information concern (Dunkel-Schetter \& Brooks, 2009). The social groups in which consumers find themselves are essential when it comes to purchasing decisions. This is because the communications in those groups about a product or a brand can influence the members purchasing behavior. Thus, members in a social group receive emotional support such as empathy and encouragement and informational support, including recommendations and suggestions from other members, which affect their purchasing behavior. Thus, support can trigger positive action among individuals (Turner \& Brown, 2010). According to past studies, social support can influence behavioral intention in an online shopping platform (Hajli, 2014; Liang et al., 2011; Liu et al., 2019; Makmor et al., 2018).

The following hypotheses are postulated for the research:

$\mathrm{H}_{1}$ : Customer trust will have a significant influence on Purchase intention

$\mathrm{H}_{2}$ : Customer trust will have a significant influence on Purchase intention

$\mathrm{H}_{3}$ : Customer trust will have a significant influence on Purchase intention

$\mathrm{H}_{4}$ : Social Support will have a significant influence on Purchase Intention

\subsection{Moderation Role of Social Support}

This current study further proposes that social support will have a moderation effect on the relationship between relationship quality and purchase intention. Literature available suggests that no much work has been done on customers' intention to purchase from an online shopping platform using social support as a moderator. Hence, it is hypothesized;

$\mathrm{H}_{5}$ : Social support will significantly moderates the relationship between relationship quality constructs and purchase intention.

\subsection{Purchase Intention}

Purchase intention is regard as a probability that an online consumer may purchase in the future. Thus, it measures the likelihood of being willing to buy a product on an online shopping platform. To (Pavlou, 2003), it is how much an online customer is willing and intends to buy in an online shopping platform. The higher the intention, the more likely the purchase is to be made. Purchase intention is a key indicator that can be used to forecast consumption behavior (Fishbein \& Ajzen, 1975).

\section{Methodology}

This research focused on Ghanaian online consumers to test the concept model. Customer Trust, Commitment, and Satisfaction served as the independent variable while Purchase Intention served as the dependent variable. The 
study was moderated by Social Support, measured by the combination of Emotional and Informational Support. A web-survey was employed, using a 7-point Likert scale from 1 (Strongly Disagree) to 7 (Strongly Agree), to collect responses from the participants. The items were adopted from past studies (Hajli, 2014; Hong \& Cha, 2013 ; Liang et al., 2011; Prendergast et al., 2010; Sahadev \& Purani, 2008) and were modified to suits this current research context.

The convenience sampling method was employed to solicit responses from the respondents. All the respondents are Ghanaian consumers who purchase from an online shopping platform. To ensure validity, the drafted questionnaire was reviewed by three doctoral students; two of those students majored in e-commerce and the other in international business. The feedback obtained from them was considered for a revised version. A total of 304 responses were recollected. The present study employs Statistical Package for Social Science (SPSS) version 26.0 to assess the demographic information using frequencies and percentages. Smart PLS 3.2.9 was employed to assess the measurement and the structural model (Ringle et al., 2015) using Partial Least Square.

\section{Results and Discussion}

4.1 Respondents Demographic Information

The results from Table 1 reveals that the majority of the respondents who participated in the survey were in the age range of $18-25$ years $(46.1 \%)$, followed by $26-30$ years $(32.9 \%)$, and then $41-50$ years $(11.5 \%), 51-60$ years $(2.6 \%)$ and $0.3 \%$ were less than 18 years.

Table 1 Demographic Information of Respondent $n=304$

\begin{tabular}{|l|l|l|l|}
\hline Variables & Characteristics & Frequency & Percentage \\
\hline & Less than 18 & 1 & 0.3 \\
& $18-25$ & 140 & 46.1 \\
Age (in years) & $26-30$ & 100 & 32.9 \\
& $31-40$ & 20 & 6.6 \\
& $41-50$ & 35 & 11.5 \\
& $51-60$ & 8 & 2.6 \\
\hline \multirow{3}{*}{ Gender } & Female & 136 & 44.7 \\
& Male & 168 & 55.3 \\
\hline \multirow{5}{*}{ Educational Level } & Senior High School & 13 & 4.3 \\
& Diploma & 58 & 19.1 \\
& Degree & 198 & 65.1 \\
& Masters & 33 & 10.9 \\
& PhD & 2 & 0.7 \\
\hline \multirow{5}{*}{ (in years) } & Less than 1 & 99 & 32.6 \\
& $1-3$ & 114 & 37.5 \\
& $4-6$ & 31 & 10.2 \\
\hline
\end{tabular}

More than half of the respondents (55.3\%) were males, and the remaining (44.7\%) were females. In terms of their educational level, $65.1 \%$ of them were Bachelor Degree holders, while 19.1\% were Diploma holders, $10.9 \%$ had Master's Degree, 4.3\% had Senior High School Certificate, and 0.7\% had a Ph.D. Regarding their online shopping experiences, $37.5 \%$ had 1-3 years experience, $32.6 \%$ had less than a year experience, $18.1 \%$ had $7-10$ years experience, $10.2 \%$ had $4-6$ years experience, and $1.6 \%$ of the respondents had over 10 years of e-commerce shopping experience. 


\subsection{Measurement Model Assessment}

Table 2 Reliability and Variability Constructs (Confirmatory Factor Analysis)

\begin{tabular}{|c|c|c|c|c|}
\hline Latent Variables & Loadings & $\begin{array}{l}\text { Composite } \\
\text { Reliability }\end{array}$ & $\begin{array}{l}\text { Average } \quad \text { Variance } \\
\text { Extracted }\end{array}$ & $\begin{array}{l}\text { Cronbach } \\
\text { Alpha }\end{array}$ \\
\hline $\begin{array}{l}\text { Customer Trust } \\
\text { CT1 }\end{array}$ & 0.829 & & & \\
\hline CT2 & 0.876 & & & \\
\hline CT3 & 0.866 & 0.909 & 0.715 & 0.867 \\
\hline CT4 & 0.810 & & & \\
\hline $\begin{array}{l}\text { Customer Commitment } \\
\mathrm{CC} 1\end{array}$ & 0.781 & & & \\
\hline $\mathrm{CC} 2$ & 0.811 & & & \\
\hline $\mathrm{CC} 3$ & 0.884 & 0.904 & 0.703 & 0.858 \\
\hline $\mathrm{CC} 4$ & 0.873 & & & \\
\hline $\begin{array}{l}\text { Customer Satisfaction } \\
\text { CS1 }\end{array}$ & 0.842 & & & \\
\hline $\mathrm{CS} 2$ & 0.916 & & & \\
\hline CS3 & 0.872 & 0.909 & 0.769 & 0.849 \\
\hline $\begin{array}{l}\text { Social Support } \\
\text { ES }\end{array}$ & 0.907 & & & \\
\hline IS & 0.913 & 0.904 & 0.825 & 0.788 \\
\hline $\begin{array}{l}\text { Purchase Intention } \\
\text { PI1 }\end{array}$ & 0.738 & & & \\
\hline PI2 & 0.787 & & & \\
\hline PI3 & 0.756 & 0.835 & 0.559 & 0.738 \\
\hline PI4 & 0.709 & & & \\
\hline
\end{tabular}

Note: Sample size $(\mathrm{N})=372, \mathrm{ES}=$ Emotional Support, IS = Informational Support

Using factor analysis, the researcher conducted a construct reliability and validity test of the measurement model. The test was conducted on the independent variables, the dependent variable, and the moderator. The internal consistency is measured by the Cronbach alpha and the composite reliability. From Table 2, the Cronbach alpha of all the constructs exceeded the threshold of 0.7 (Nunnally, 1978). Besides, the composite reliability loadings were all above 0.7 as recommended by (Hair et al., 2017).

Table 3 presents another test of discriminant validity, the Heterotrait-Monotrait Ratio (HTMT) proposed (Henseler et al., 2015).

Table 3 Heterotrait-Monotrait ratio (HTMT)

\begin{tabular}{|l|l|l|l|l|l|}
\hline Variables & CT & CC & CS & SS & PI \\
\hline CT & & & & & \\
\hline CC & 0.758 & & & & \\
\hline CS & 0.827 & 0.775 & & & \\
\hline SS & 0.527 & 0.553 & 0.468 & & \\
\hline PI & 0.630 & 0.786 & 0.587 & 0.670 & \\
\hline
\end{tabular}

Note: CT = Customer Trust, CC = Customer Commitment, CS = Customer Satisfaction, SS = Social Support, PI $=$ Purchase Intention

The results show that HTMT ratios were lower than the most restrictive threshold of 0.90 , indicating a good discriminant validity (Henseler et al., 2015). The results from Table 2 reveal that all the items have a loading above 0.70 , while the average variance extracted were between 0.559 and 0.825 , which attained convergent validity criteria (Hair et al., 2011).

\subsection{Structural Model Assessment}

This section assesses the structural model of the study. Partial Least Squares Structural Equation Modelling (PLSSEM) was used to test the hypothesized relationships using SmartPLS 3.2.9 (Ringle et al., 2015). This was done using the bootstrapping method (5000 resamples) as recommended by Hair et al. (2016). 
Table 4. Path Coefficients of the structural Model; Direct and Total Effects of Constructs

\begin{tabular}{|l|l|l|l|l|l|l|}
\hline $\begin{array}{l}\text { Constructs } \\
\text { Effects }\end{array}$ & OS & SM & STDEV & $\begin{array}{l}\text { T-Value } \\
(|\mathrm{O} / \mathrm{STDEV}|)\end{array}$ & P-values & Conclusion \\
\hline CT - PI & 0.133 & 0.137 & 0.069 & 1.930 & 0.054 & Not Supported \\
\hline CS - PI & 0.014 & 0.017 & 0.074 & 1.187 & 0.852 & Not Supported \\
\hline CC - PI & 0.422 & 0.416 & 0.086 & 4.889 & $0.000^{* * *}$ & Supported \\
\hline SS - PI & 0.284 & 0.284 & 0.056 & 5.069 & $0.000^{* * *}$ & Supported \\
\hline CT - SS - PI & 0.141 & 0.147 & 0.065 & 2.178 & $0.029^{* *}$ & Supported \\
\hline CS - SS - PI & -0.046 & -0.041 & 0.073 & 0.624 & 0.532 & Not Supported \\
\hline CC - SS - PI & -0.050 & -0.053 & 0.068 & 0.741 & 0.459 & Not Supported \\
\hline
\end{tabular}

Note: $* * *$ p-value $<0.01, * *$ p-value $<0.05$, OS $=$ Original Sample, SM $=$ Sample Mean, STDEV $=$ Standard Deviation, $\mathrm{CT}=$ Customer Trust, $\mathrm{CC}=$ Customer Commitment, $\mathrm{CS}=$ Customer Satisfaction, $\mathrm{SS}=$ Social Support, PI $=$ Purchase Intention

The path coefficient of the constructs has a standardized value ranging from -1 and 1 . The closer the path coefficients are geared towards 1 , the stronger the forecast relationship, and the closer it is to 0 , the weaker the relationship. Table 4 shows a positive relationship among all the constructs except the moderating role of Social Support between Customer Satisfaction and Purchase Intention and between Customer Commitment and Purchase Intention, although the magnitude of the effect differs across.

The results from Table 4 shows that Customer Trust did not have a significant influence on Purchase Intention $(\beta=0.133, t$-value $=1.930, p$-value $=0.054)$. In the same fashion, Customer Satisfaction did not have a significant influence on Purchase Intention $(\beta=0.014$, $t$-value $=1.187$, $p$-value $=0.852)$. Despite this, the relationship between Customer Commitment and Purchase Intention was found to be positive and significant $(\beta=0.422$, $t$-value $=4.889$, $\mathrm{p}$-value $=0.000)$. Again, Social Support had a significant and positive influence on Purchase Intention $(\beta=0.284$, t-value $=5.069, \mathrm{p}$-value $=0.000)$. Regarding the moderation effects, the results from Table 4 showed that the relationship between Customer Trust and Purchase Intention was moderated by Social Support $(\beta=0.141$, t-value $=2.178, \mathrm{p}$-value $=0.029)$. However, Social Support did not have a moderation effect on Customer Satisfaction and Purchase Intention $(\beta=-0.046$, $\mathrm{t}$-value $=0.624, \mathrm{p}$-value $=0.532)$ and Customer Commitment and Purchase Intention $(\beta=-0.050$, t-value $=0.741, p$-value $=0.459)$.

\subsection{Discussion}

This research's aimed to determine the influence of customer trust, satisfaction, and commitment on purchase intention among Ghanaian consumers while moderated by social support. The results revealed that customer trust had no significant influence on purchase intention contrasting earlier findings (Sullivan \& Kim, 2018; Yin et al., $\underline{2019)}$.

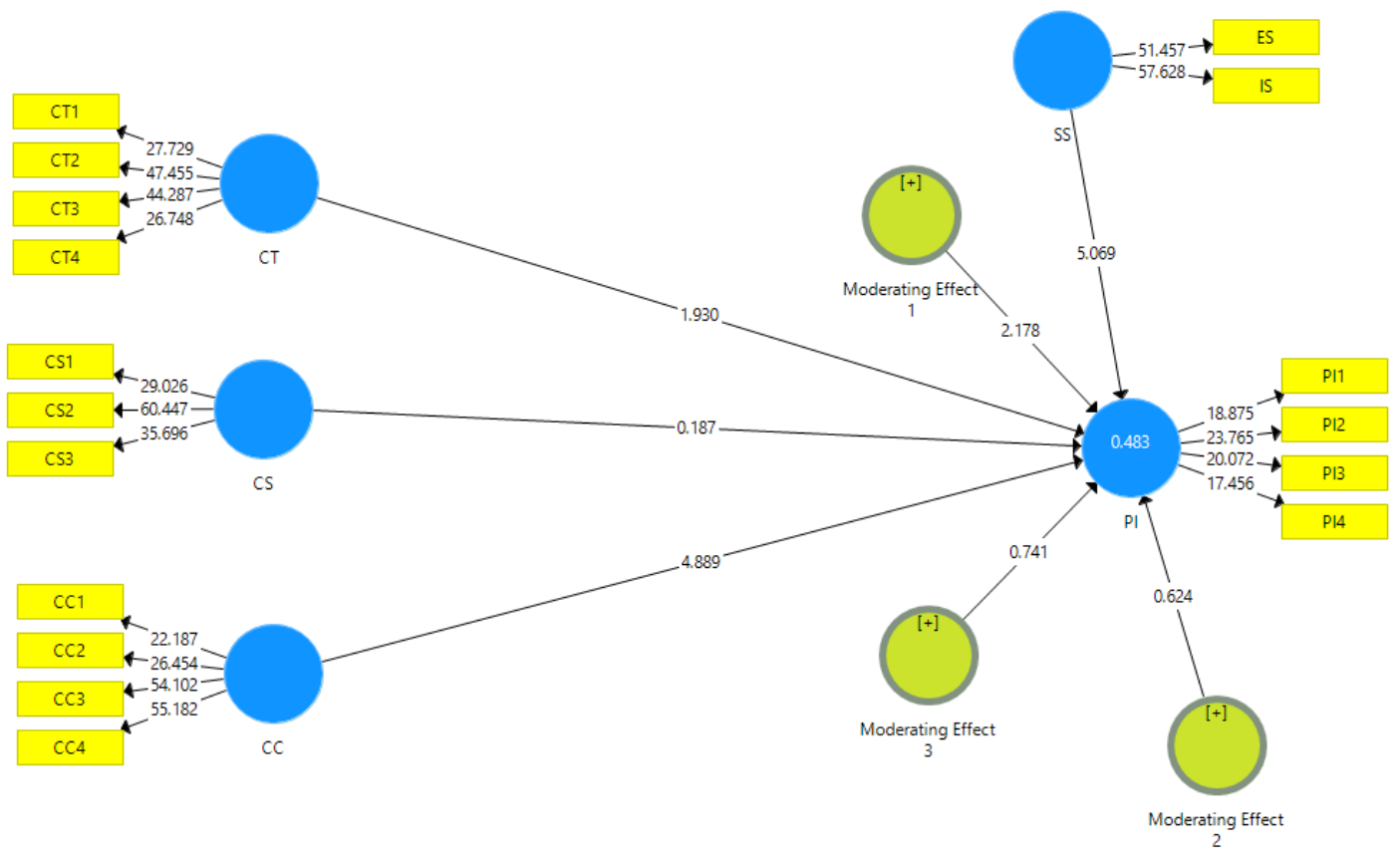

Figure 1: Structural Model

At the same time, customer satisfaction did not have a significant on purchase intention. The finding is the same as Shin et al. (2013) who found out that satisfaction does not influence behavioral intention. In contrast to 
these findings, customer commitment had a significant and positive influence on purchase intention. The finding confirms with (Amoako et al., 2019; Hazra, 2013). Similarly, Social Support had a significant and positive influence on purchase intention support earlier findings of Hajli (2014) and Makmor et al. (2018).

Social Support significantly moderates the relationship between customer trust and purchase intention. Despite this, social support did not have a moderating effect on the relationship between customer satisfaction and purchase intention. Lastly, the relationship between customer commitment and purchase intention was not moderated by social support.

\section{Research Implications}

\subsection{Theoretical Implication}

This research contributes to research by assessing relationship quality on online shopping. Although past studies have widely investigated relationship quality, relatively few studies have focused on its role in the Ghanaian context. Besides, most of the available studies use relationship quality to assess a customer repurchase intention in an online shopping platform. Also, online consumer shopping patterns vary from country-by-country because of cultural differences, technological differences, and others. This study adds up to research about relationship quality in an online shopping by exploring the moderating role of social support. Research on the moderation of social support in online shopping is minimal, and this study is one of the pioneering research to explore that area.

\subsection{Practical Implication}

The research findings make a significant contribution for policymakers, marketing management, and educators interested in exploring the Ghanaian market. The current research reveals that both customer trust and satisfaction have no significant on purchase intention. This finding gives an idea to online retailers in the whole world that Ghanaian consumers do not consider trust and satisfaction if they want to buy online. This could be attributed to an improvement in online shopping by the platform owners. The findings also imply that customers do not consider the relationship they have with an e-retailer when shopping online; hence, an e-retailer needs to improve their relationships with online consumers to sustain them. The research further reveals that commitment can influence a customer's purchase intention. Thus, when an online consumer becomes committed to an e-retailer or a brand, they are likely to buy from them. The findings also suggest that social support will influence purchase intention. As part of their purchasing process, Ghanaian consumers may receive advice, recommendations, encouragement, among others, from their friends in a social group, and these tend to influence their purchase intention.

Consequently, e-retailers should offer quality products and effective customer service so that early consumers can recommend their products to new consumers, where necessary. Finally, social support has had a moderating effect on the relationship between customer trust and purchase intention although it did not play a moderation role between customer satisfaction and purchase intention and between customer commitment and purchase intention. Thus, social support strengthens the relationship between customer trust and purchase intention. However, it does not affect the strength of the relationship between customer satisfaction and purchase intention and the relationship between customer commitment and purchase intention.

\section{Limitations and Suggestions}

This study, like many previous studies, has some limitations. First, the research scope was limited to Ghana only. Consequently, the findings may not be applicable in other countries. Future research should test the hypotheses in other countries, particularly the emerging economies where online shopping is not predominant. Also, the study focused on customers' intention to purchase but not actual purchase. Future research should research on online consumers' actual purchases. Several factors can affect customer purchase intention, but this study focused on trust, satisfaction, and commitment. Future research should explore other factors that can influence customers' intention to purchase. Lastly, the research data was collected at a single point in time. As such, a longitudinal study should be conducted to help extend an understanding of the causal relationships between the constructs.

Disclosure Statement: The author declares no conflict of interest.

\section{References}

Ali, A., \& Bhasin, J. (2019). Understanding Customer Repurchase Intention in E-commerce: Role of Perceived Price, Delivery Quality, and Perceived Value. Jindal Journal of Business Research, 8(2), 142-157. https://doi.org/10.1177/2278682119850275

Allaway, A. W., Gooner, R. M., Berkowitz, D., \& Davis, L. (2006). Deriving and exploring behavior segments within a retail loyalty card program. European Journal of Marketing, 40(11-12), 1317-1339. https://doi.org/10.1108/03090560610702830

Amoako, G. K., Kutu-Adu, S. G., Caesar, L. D., \& Neequaye, E. (2019). Relationship Marketing and Repurchase Intention in Ghana's Hospitality Industry: An Empirical Examination of Trust and Commitment. Journal of 
Relationship Marketing, 18(2), 77-107. https://doi.org/10.1080/15332667.2018.1534059

Beldad, A., De Jong, M., \& Steehouder, M. (2010). How shall i trust the faceless and the intangible? A literature review on the antecedents of online trust. In Computers in Human Behavior (Vol. 26, Issue 5, pp. 857-869). Pergamon. https://doi.org/10.1016/j.chb.2010.03.013

Dunkel-Schetter, C., \& Brooks, K. (2009). The nature of social support. In H. T. Reis \& S. Sprecher (Eds.), Encyclopedia of human relationships ((Eds.), pp. 1565-1570). Sage Publications. https://www.amazon.com/Encyclopedia-Human-Relationships-Reference-Publication/dp/1412958466

Eisa Nauroozi, S., Korahi Moghadam, S., \& Bank, G. (2015). The Study of Relationship Marketing with Customer Satisfaction and Loyalty (Case Study: Customers of Ghavamin Bank in Sistan and Baluchestan Province). International Journal of Innovation and Research in Educational Sciences, 2(2), 96-101. http://www.ijires.org/administrator/components/com_jresearch/files/publications/IJIRES_224_Final.pdf

Fishbein, M., \& Ajzen, I. (1975). Belief, attitude, intention, and behavior: An introduction to theory and research. Addison-Wesley. https://people.umass.edu/aizen/f\&a1975.html

Gilaninia, S., Almani, A. M., Pournaserani, A., \& Javad, S. (2011). Relationship Marketing: a New Approach to Marketing in the Third Millennium. Australian Journal of Basic and Applied Sciences, 5(5), 787-799. https://citeseerx.ist.psu.edu/viewdoc/download?doi=10.1.1.1087.6357\&rep=rep1\&type=pdf

Grabner-Kräuter, S., \& Kaluscha, E. A. (2003). Empirical research in on-line trust: A review and critical assessment. International Journal of Human Computer Studies, 58(6), 783-812. https://doi.org/10.1016/S10715819(03)00043-0

Gustafsson, A., Johnson, M. D., \& Roos, I. (2005). The Effects of Customer Satisfaction, Relationship Commitment Dimensions, and Triggers on Customer Retention. Journal of Marketing, 69(4), 210-218. https://doi.org/10.1509/jmkg.2005.69.4.210

Hair, J. F., Hult, G. T. M., Ringle, C. M., \& Sarstedt, M. (2016). A Primer on Partial Least Squares Structural Equation Modeling (PLS-SEM). In Sage Publications (2nd editio). https://us.sagepub.com/en-us/nam/aprimer-on-partial-least-squares-structural-equation-modeling-pls-sem/book244583

Hair, J. J. F., Sarstedt, M., Ringle, C. M., \& Gudergan, S. P. (2017). Advanced Issues in Partial Least Squares Structural Equation Modeling. Sage Publishing. https://us.sagepub.com/en-us/nam/advanced-issues-inpartial-least-squares-structural-equation-modeling/book243803

Hair, Joe F., Ringle, C. M., \& Sarstedt, M. (2011). PLS-SEM: Indeed a silver bullet. Journal of Marketing Theory and Practice, 19(2), 139-152. https://doi.org/10.2753/MTP1069-6679190202

Hajli, M. N. (2014). The role of social support on relationship quality and social commerce. Technological Forecasting and Social Change, 87, 17-27. https://doi.org/10.1016/j.techfore.2014.05.012

Hazra, S. G. (2013). An investigating into customer satisfaction, customer commitment and customer trust: A study in Indian banking sector. Journal of Arts, Social \& Commerce, 4(1), 96. https://search.proquest.com/openview/23de5505ffa0d25df8c190c5d1f42d58/1.pdf?pqorigsite $=$ gscholar\&cbl $=556342$

Hennig-Thurau, T. (2000). Relationship Quality and Customer Retention through Strategic Communication of Customer Skills. Journal of Marketing Management, 16(1-3), 55-79. https://doi.org/10.1362/026725700785100497

Henseler, J., Ringle, C. M., \& Sarstedt, M. (2015). A new criterion for assessing discriminant validity in variancebased structural equation modeling. Journal of the Academy of Marketing Science, 43(1), 115-135. https://doi.org/10.1007/s11747-014-0403-8

Hong, I. B., \& Cha, H. S. (2013). The mediating role of consumer trust in an online merchant in predicting purchase intention. International Journal of Information Management, 33(6), 927-939. https://doi.org/10.1016/j.ijinfomgt.2013.08.007

Hsu, M. H., Chang, C. M., Chu, K. K., \& Lee, Y. J. (2014). Determinants of repurchase intention in online groupbuying: The perspectives of DeLone \& McLean is success model and trust. Computers in Human Behavior, 36, 234-245. https://doi.org/10.1016/j.chb.2014.03.065

Jones, T., Fox, G. L., Taylor, S. F., \& Fabrigar, L. R. (2010). Service customer commitment and response. Journal of Services Marketing, 24(1), 16-28. https://doi.org/10.1108/08876041011017862

Kim, H.-W., Xu, Y., \& Koh, J. (2004). A Comparison of Online Trust Building Factors between Potential Customers and Repeat Customers. Journal of the Association for Information Systems, 5(10), 392-420. https://doi.org/10.17705/1jais.00056

Liang, T. P., Ho, Y. T., Li, Y. W., \& Turban, E. (2011). What drives social commerce: The role of social support and relationship quality. International Journal of Electronic Commerce, 16(2), 69-90. https://doi.org/10.2753/JEC1086-4415160204

Liu, Y., Su, X., Du, X., \& Cui, F. (2019). How Social Support Motivates Trust and Purchase Intentions in Mobile Social Commerce. Revista Brasileira de Gestão de Negócios, 21(4), 839-860. http://dx.doi.org/10.7819/rbgn.v21i5.4025 
Makmor, N., Alam, S. S., \& Aziz, N. A. (2018). Social Support, Trust and Purchase Intention in Social Commerce Era. Int. J Sup. Chain. Mgt, 7(5), 572-581. https://core.ac.uk/download/pdf/230747949.pdf

Murphy, E. C., \& Murphy, M. A. (2002). Leading on the edge of chaos: The 10 critical elements for success in volatile times. Prentice Hall. https://www.amazon.com/Leading-Edge-Chaos-CriticalElements/dp/0735203121

Nunnally, J. C. (1978). Psychometric theory. McGraw-Hill. https://www.worldcat.org/title/psychometrictheory/oclc/3167590

Parker, C., \& Mathews, B. P. (2001). Customer satisfaction: Contrasting academic and consumers' interpretations. Marketing Intelligence \& Planning, 19(1), 38-44. https://doi.org/10.1108/02634500110363790

Pavlou, P. A. (2003). Consumer acceptance of electronic commerce: Integrating trust and risk with the technology acceptance model. International Journal of Electronic Commerce, 7(3), 101-134. https://doi.org/10.1080/10864415.2003.11044275

Prendergast, G., Ko, D., \& Yuen, S. Y. V. (2010). Online word of mouth and consumer purchase intentions. International Journal of Advertising, 29(5), 687-708. https://doi.org/10.2501/s0265048710201427

Ringle, C. M., Wende, S., \& Becker, J.-M. (2015). SmartPLS 3. Boenningstedt. In SmartPLS GmbH. http://www.smartpls.com

Sahadev, S., \& Purani, K. (2008). Modelling the consequences of e-service quality. Marketing Intelligence and Planning, 26(6), 605-620. https://doi.org/10.1108/02634500810902857

Shin, J. I., Chung, K. H., Oh, J. S., \& Lee, C. W. (2013). The effect of site quality on repurchase intention in Internet shopping through mediating variables: The case of university students in South Korea. International Journal of Information Management, 33(3), 453-463. https://doi.org/10.1016/j.ijinfomgt.2013.02.003

Suh, B., \& Han, I. (2003). The impact of customer trust and perception of security control on the acceptance of electronic commerce. International Journal of Electronic Commerce, 7(3), 135-161. https://doi.org/10.1080/10864415.2003.11044270

Sullivan, Y. W., \& Kim, D. J. (2018). Assessing the effects of consumers' product evaluations and trust on repurchase intention in e-commerce environments. International Journal of Information Management, 39, 199-219. https://doi.org/10.1016/j.ijinfomgt.2017.12.008

Tsai, H. T., \& Huang, H. C. (2007). Determinants of e-repurchase intentions: An integrative model of quadruple retention drivers. Information and Management, 44(3), 231-239. https://doi.org/10.1016/j.im.2006.11.006

Turner, J. R., \& Brown, R. L. (2010). Social Support and Mental Health. In T. Scheid \& T. Brown (Eds.), $A$ handbook for the study of mental health: Social contexts, theories, and systems ((Eds.), pp. 200-212). Cambridge University Press. https://link.springer.com/content/pdf/10.1007\%2F978-94-007-4276-5.pdf

Verhagen, T., Meents, S., \& Tan, Y. H. (2006). Perceived risk and trust associated with purchasing at electronic marketplaces. European Journal of Information Systems, 15(6), 542-555. https://doi.org/10.1057/palgrave.ejis.3000644

Wu, J. J., Chen, Y. H., \& Chung, Y. S. (2010). Trust factors influencing virtual community members: A study of transaction communities. Journal of Business Research, 63(9-10), 1025-1032. https://doi.org/10.1016/j.jbusres.2009.03.022

Yang, D.-J., Wu, J. M., \& Wang, K.-I. (2010). Relationship Quality, Relationship Value, Purchasing Intention: An Empirical Study in the Retail Industry in the USA, Japan and Taiwan. Asian Journal of Arts and Sciences, 1(2), 155-166. https://doi.org/10.30168/AJAS.201012.0001

Yin, X., Wang, H., Xia, Q., \& Gu, Q. (2019). How Social Interaction Affects Purchase Intention in Social Commerce: A Cultural Perspective. Sustainability, 11(8), 2423. https://doi.org/10.3390/su11082423 